\title{
Birth of rats following nuclear exchange at the 2-cell stage
}

\author{
Sangho Roh, Jitong Guo, Nakisa Malakooti, John R. Morrison, Alan O. Trounson and Zhong Tao Du \\ Monash Institute of Reproduction and Development, Monash University, 246 Clayton Road, Clayton, VIC 3168, Australia
}

Date submitted: 25.1.03. Date accepted: 15.5 .03

\section{Summary}

We report full-term development of nuclear transfer embryos following nuclear exchange at the 2-cell stage. Nuclei from 2-cell rat embryos were transferred into enucleated 2-cell embryos and developed to term after transfer to recipients (NT2). Pronuclear exchange in zygotes was used for comparison (NT1). Zygotes and 2-cell embryos were harvested from 4-week-old female Sprague-Dawley rats. Nuclear transfer was performed by transferring the pronuclei or karyoplasts into the perivitelline space of recipient embryos followed by electrofusion to reconstruct embryos. Fused couplets were cultured for 4 or $24 \mathrm{~h}$ before being transferred into day 1 pseudopregnant recipients (Hooded Wistar) at the 1- or 2-cell stage. In vitro culture was also carried out to check the developmental competence of the embryos. In vitro development to the blastocyst stage was not significantly different between the two groups (NT1, 34.3\%; NT2, 45.0\%). Two of three recipients from NT1 and two of five recipients from NT2 became pregnant. Six pups ( 3 from NT1, 3 from NT2) were delivered from the four foster mothers. Three female pups survived; 2 from NT1 and 1 from NT2. At 2 months of age these pups appeared healthy, and were mated with Sprague-Dawley males. One rat derived from NT1 delivered 15 pups ( 5 males, 10 females) as did the rat from NT2 (7 males, 8 females). Our results show that by using karyoplasts from 2-cell stage embryos as nuclear donors and reconstructing them with enucleated 2-cell embryos, healthy rats can be produced.

Keywords: Nuclear transfer, Rat, Recipient cytoplasm, 2-cell stage embryo

\section{Introduction}

Attempts to produce rats from nuclear transfer (NT) have been very limited (Kato et al., 2001; Iannaccone et al., 2001; Hayes et al., 2001; Kono et al., 1988). There is only one report of the birth of rats by NT using the zygote as donor nucleus and recipient cytoplasm (Kono et al., 1988). In rats, a high rate of spontaneous activation occurs in ovulated oocytes during in vitro culture (Keefer \& Schuetz, 1982). Activated oocytes extrude the second polar body within 60-90 min of culture, and show scattered chromosomes, a state termed metaphase III (MIII). When reaching this MIII state, oocytes exhibit very low rates of embryonic cleavage following induced activation. This represents a major

All correspondence to: Dr Zhong Tao Du, Monash Institute of Reproduction and Development, Monash University, 246 Clayton Road, Clayton, VIC 3168, Australia. Tel: +61 3 95947359. Fax: +61 3 95947311. e-mail: zhongtao.du@med. monash.edu.au obstacle for somatic cell NT in the rat, as control of activation is a crucial step for successful NT.

Enucleated 2-cell embryos have been widely used as a recipient cytoplasm for mouse embryonic NT, and it has also been shown that a nucleus from 4- or 8-cell blastomeres can support development to term when transferred to cytoplasm from a 2-cell stage embryo (Tsunoda et al., 1987). In contrast, none of the enucleated mouse zygotes into which nuclei from more advanced embryos were placed was able to develop to blastocysts in vitro (McGrath \& Solter, 1983). In the rat there are no reports using 2-cell embryos as the recipient cytoplasm in a NT programme.

After the initial success of cloning in the mouse (Wakayama et al., 1998), cloned mice from somatic cells were subsequently also generated by serial NT (Ono et al., 2001). In this serial NT system, a nucleus is first transferred to an unfertilised oocyte, and then the resultant pronucleus is again transferred into an enucleated zygote (Kwon \& Kono, 1996). Tsunoda \& Kato (1997, $1998)$ then used 2-cell stage embryos as recipient cytoplasm instead of a zygote for the second-round NT. In 
this protocol, donor karyoplasts are also derived from 2-cell NT embryos. Owing to difficulties associated with somatic cell NT in the rat (Iannaccone et al., 2001; Kato et al., 2001) we have explored the possibility of using serial NT with fertilised embryos as an alternative. In addition, using 2-cell cytoplasts may allow selection of more developmentally competent embryos, since they have already passed the maternal-embryonic genomic transition. However, before the application of serial NT, the success of embryonic cell NT using 2-cell embryos should be demonstrated in the rat.

In this study, the nuclei from 2-cell rat embryos were transferred into enucleated 2-cell embryos in the same cell cycle stage. These reconstructed embryos were developed to term after being transferred to a foster mother. We report full-term development of NT embryos by using karyoplasts and cytoplasts derived from the 2-cell stage embryos.

\section{Materials and methods}

\section{Reagents and media}

All inorganic and organic compounds were purchased from Sigma Chemical Co (St Louis, MO) unless otherwise stated. All the media used here were based on mR1ECM (Miyoshi et al., 1997). Embryo manipulations were carried out in Hepes-buffered mR1ECM (HR1ECM) at room temperature in air.

\section{Isolation of zygotes and 2-cell stage embryos}

Sprague-Dawley outbred (SD/OB) female rats at the age of 4 weeks were superovulated by intraperitoneal injections of $10 \mathrm{IU} / \mathrm{ml}$ equine chorionic gonadotropin (eCG) and $10 \mathrm{IU} / \mathrm{ml}$ human chorionic gonadotropin (hCG; Intervet, Castle Hill, NSW) given $48 \mathrm{~h}$ apart. The females were mated with males of the same strain after hCG injection. The day on which spermatozoa were found in the vagina was taken as day 1 of pregnancy. Zygotes were removed from the ampullary regions by puncturing on day 1 of pregnancy and freed from cumulus cells by treatment with hyaluronidase (300 IU $/ \mathrm{ml}$, bovine testis). Two-cell stage embryos were flushed from the oviducts on day 2 of pregnancy with HR1ECM.

\section{Enucleation and nuclear transfer (Fig. 1)}

Zygote to zygote (NT1). All micromanipulation steps were performed between 18 and $22 \mathrm{~h}$ after hCG injection. Zygotes were placed in HR1ECM containing cytochalasin B $(5 \mathrm{mg} / \mathrm{ml})$. After the zona pellucida had been slit with a microneedle, both female and male pronuclei were drawn into a pipette with an approxi-
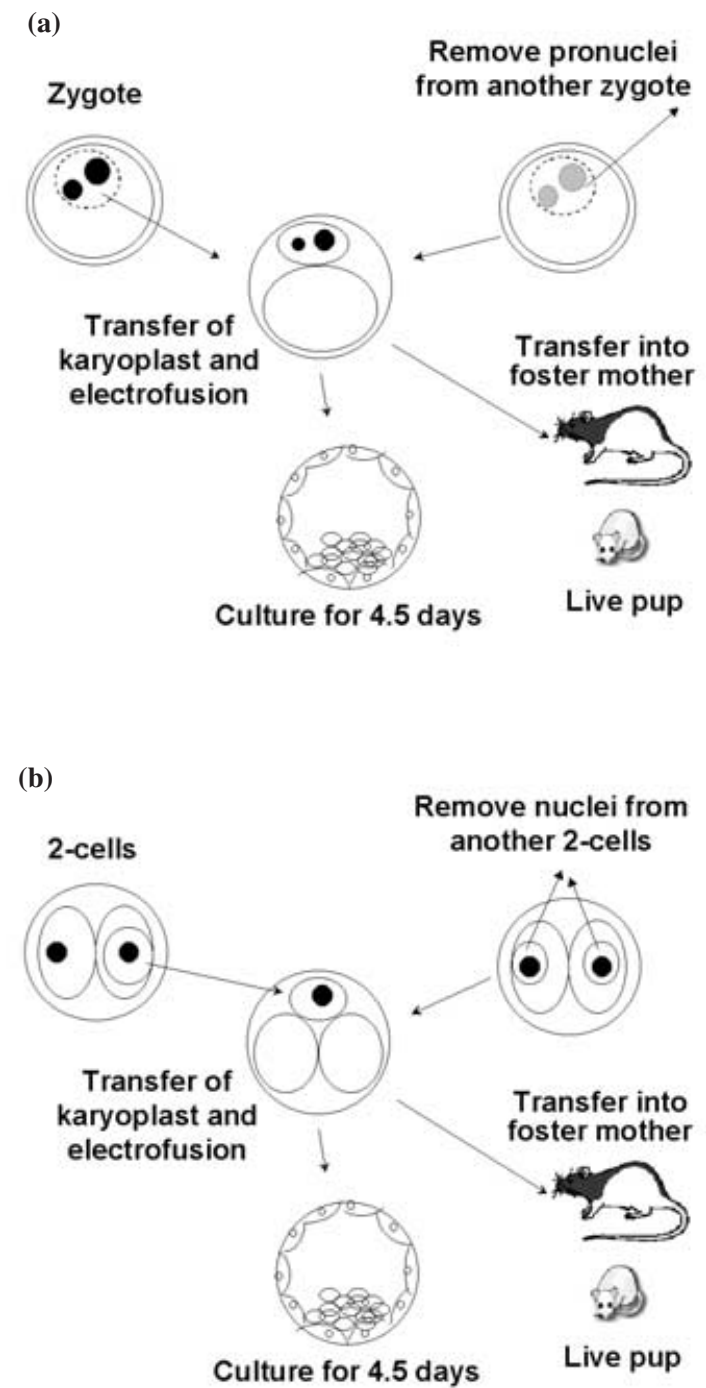

Figure 1 The nuclear transfer procedure used in this study. (a) Zygote to zygote nuclear transfer (b) 2-cell to 2-cell nuclear transfer

mate inner diameter of $15 \mathrm{~mm}$., then pulled gently away from the zygote until a stretched cytoplasmic bridge was pinched off. The karyoplast containing both pronuclei was transferred into an enucleated zygote of different origin.

Two-cell to two-cell (NT2). All micromanipulation steps were performed between 42 and $46 \mathrm{~h}$ after hCG injection. Blastomere enucleation was performed by removing the nuclei (karyoplasts) from both blastomeres of the recipient 2-cell embryos in medium containing cytochalasin B. Nuclear transfer was performed by transferring a single karyoplast from a different embryo into another.

\section{Electrofusion, in vitro culture and embryo transfer}

The reconstructed embryos were fused by the electrofusion method $(1.5 \mathrm{kV} / \mathrm{cm}, 60 \mathrm{~ms}$, double pulses). The 
procedure was repeated once if initial fusion was not successful. The fused couplets were cultured in vitro for 4 or $24 \mathrm{~h}$ before being transferred into day 1 pseudopregnant recipients (Hooded Wistar) at the 1or 2-cell stage with 10-20 embryos in each oviduct. Some NT embryos were instead cultured in vitro for 5 days for comparison of development to the blastocyst stage.

\section{Statistical analysis}

Differences between groups were analysed by chisquare test.

\section{Results}

In vitro development to the blastocyst stage was not significantly different between the NT1 and NT2 groups $(34.3 \%, 34 / 99$ and $45.0 \%, 18 / 40$ respectively; Table 1). Two of the three recipients of NT1 embryos and two of the five recipients of NT2 embryos became pregnant following transfer. Six pups (3 from NT1, 3 from NT2) were born alive from the four foster mothers. Two pups from NT1 and one pup from NT2 survived; the other 3 pups died during the first $24 \mathrm{~h}$ following birth (Table 2, Fig. 2). The three surviving rats were all females. All three rats had a low density of hair around their head until they reached the age of 3 weeks (Fig. 2).

At 2 months of age the pups remained apparently healthy, and mated successfully with fertile SD males. One of the two rats derived from NT1 delivered 15 pups (5 males, 10 females) at term and the rat from NT2 transfer had 15 pups born alive at term $(7$ males, 8 females). All pups from these two litters appeared normal. The other NT1-derived rat showed four implantation scars but no pups.

\section{Discussion}

The present study demonstrates that reconstructed rat 2-cell embryos which receive 2-cell stage karyoplasts

Table 1 In vitro development of nuclear transfer embryos when using zygotic or 2-cell embryonic karyoplast as donor nucleus

\begin{tabular}{|c|c|c|c|c|c|}
\hline Group & $\begin{array}{c}\text { Donor } \\
\text { (karyoplast) }\end{array}$ & $\begin{array}{l}\text { Recipient } \\
\text { (cytoplast) }\end{array}$ & Fused & Cleavage $(\%)$ & Blastocysts (\%) \\
\hline NT1 & Zygote & Zygote & 99 & $98(98.9)$ & $34(34.3)$ \\
\hline NT2 & 2-cell & 2-cell & 40 & $37(92.5)$ & $18(45.0)$ \\
\hline IVC-1 & \multicolumn{2}{|c|}{$\begin{array}{l}\text { Fertilised embryos cultured } \\
\text { in vitro from zygote stage }\end{array}$} & & $100^{*}$ & $51(51.0)^{a}$ \\
\hline IVC-2 & \multicolumn{2}{|c|}{$\begin{array}{l}\text { Fertilised embryos cultured } \\
\text { in vitro from 2-cell stage }\end{array}$} & & 90 & $59(65.6)^{b}$ \\
\hline
\end{tabular}

NT1, zygote to zygote nuclear transfer; NT2, 2-cell to 2-cell nuclear transfer.

"Embryos not cleaved were excluded from the experimental group.

Two groups (NT vs IVC) were statistically analysed separately.

Values with different superscripts within the same column are significantly different, ${ }^{a b} p<0.05$.

Table 2 Embryo transfer results of nuclear transfer embryos

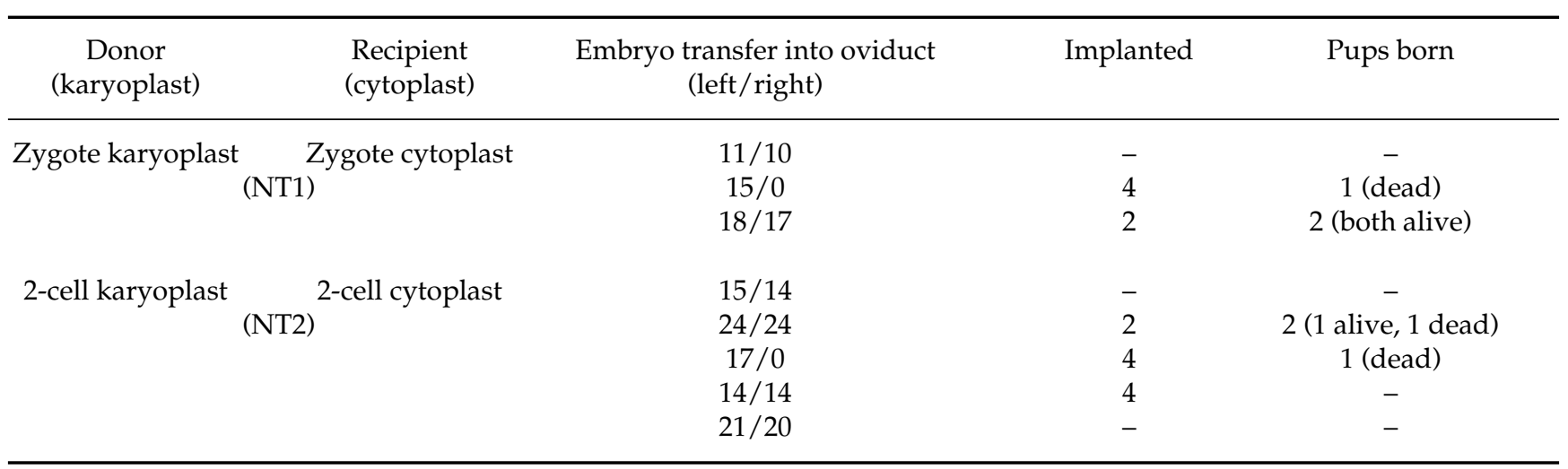




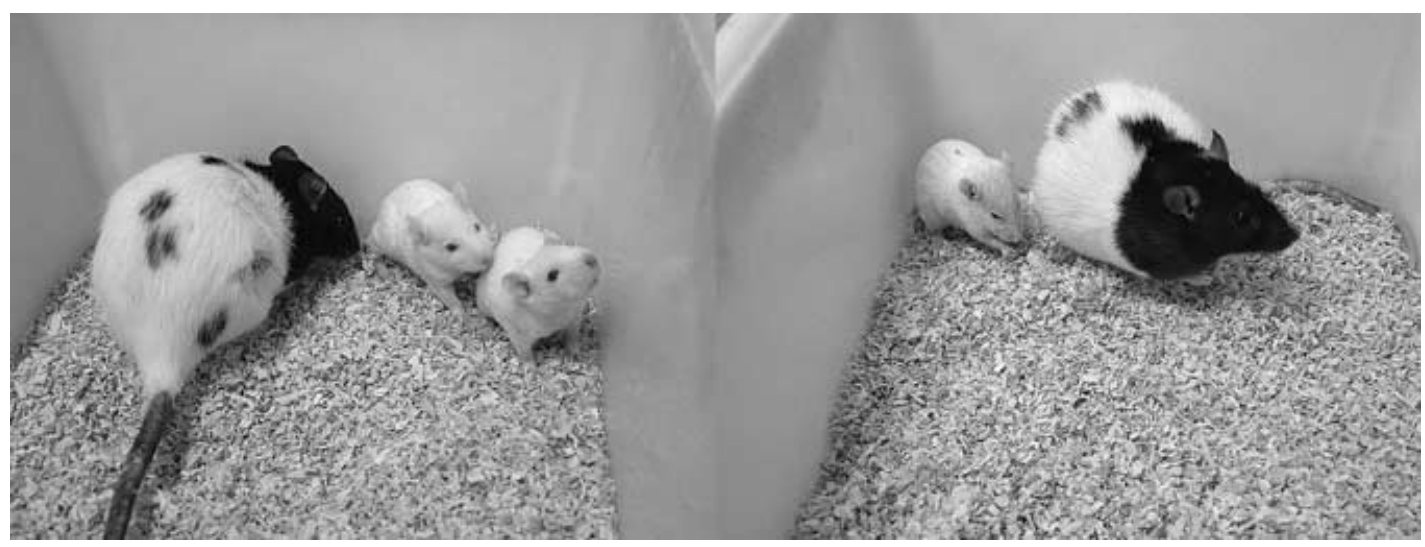

Figure 2 Rats produced by embryonic cell nuclear transfer. Left: A foster mother with pups obtained from zygote to zygote nuclear transfer; Right: A foster mother with a pup obtained from 2-cell to 2-cell nuclear transfer.

can develop to term after embryo transfer to foster mothers, as has been reported for mice (Tsunoda \& Kato, 1997). Previously there has been only one report of the birth of rats by NT. This study used the zygotestage embryo as both donor nucleus and recipient cytoplasm (Kono et al., 1988). In the present study the assessment of in vitro development of reconstructed embryos showed that rat NT embryos derived from 2cell karyoplast and cytoplast as well as zygotic karyoplast and cytoplast were developmentally competent to the blastocyst (Table 1). Interestingly, the timing of blastocyst formation was not different between the two groups. In the preliminary study, we found that most 2-cell stage embryos form blastocysts within 3.5 days of in vitro culture. Culture of electrofused 2-cell embryos to form tetraploid embryos also resulted in blastocysts within 3.5 days of in vitro culture (data not shown). Although these fused embryos are morphologically 1-cell embryos, they developed at the same rate as normal 2-cell embryos. However, following NT, the reconstructed embryo with a 2-cell stage karyoplast donor needed one additional day to reach the blastocyst stage. This indicated development at the rate of a 1-cell instead of a 2-cell embryo. The presence of only one 2-cell karyoplast in a NT embryo having the same cytoplasmic volume as a 1-cell embryo may be one of the reasons for this delay in development.

In our rat somatic cell NT programme, we found that less than $50 \%$ of embryos develop to the 2-cell stage, and there is no blastocyst development after in vitro culture (Roh et al., 2002), whereas more than $50 \%$ of NT embryos developed to the blastocyst stage in mice (Wakayama \& Yanagimachi, 2001). It is known that transcription of embryonic genes is initiated and that maternal genes are inactivated from the 2-cell stage in rodents (Johnson et al., 1984), resulting in the synthesis of new proteins from the 2-cell stage (Flach $e t$ al., 1982). We have found 2-cell stage embryos recovered from the oviduct are developmentally more com- petent than zygotes (Table 1). Hence, if 2-cell stage karyoplasts are used for second-round NT, this may result in more developmentally competent embryos following serial NT. A major obstacle in this approach would be the necessity for synchronisation of the cell cycle. In the preliminary study, we failed to obtain blastocysts in vitro when a 4- or 8-cell karyoplast was transferred to cytoplasm from a 2-cell stage embryo in the rat (data not shown). Although it has been shown that a nucleus from 4- or 8-cell blastomeres could support development to term when transferred to 2-cell cytoplasts (Tsunoda et al., 1987), this technology was not applicable to the rat embryonic NT programme.

Our results suggest that the reconstructed embryos produced by using karyoplasts from 2-cell embryos as the nuclear donors and enucleated 2-cell embryos as the recipient cytoplasm, developed to the blastocyst stage at the same rate as the embryos derived from 1cell stage NT embryos. Healthy rats were produced by these procedures. To the best of our knowledge, this is the first report of the birth of rats by using 2-cell stage embryos as the recipient cytoplasm. Further studies, such as cell cycle synchronisation, are needed before the NT2 strategy could be incorporated into a somatic cell NT programme.

\section{References}

Flach, G., Johnson, M.H., Braude, P.R., Taylor, R.A.S. \& Bolton, V.N. (1982). The transition from maternal to embryonic control in the two-cell mouse embryo. EMBO J. 1, 681-6.

Hayes, E., Galea, S., Verkuylen, A., Pera, M., Morrison, J., Lacham-Kaplan, O. \& Trounson, A. (2001). Nuclear transfer of adult and genetically modified fetal cells of the rat. Physiol. Genomics 5, 193-203.

Iannaccone, P., Taborn, G. \& Garton, R. (2001). Preimplantation and postimplantation development of rat embryos cloned with cumulus cells and fibroblasts. Zygote 9, 135-43. 
Johnson, M.H., McConnell, J. \& VanBlerkom, J. (1984). Programmed development in the mouse embryo. J. Embryol. Exp. Morphol. 83, 197-231.

Kato, M., Hirabayashi, M., Aoto, T., Ito, K., Ueda, M. \& Hochi, S. (2001). Strontium-induced activation regimen for rat oocytes in somatic cell nuclear transplantation. $J$. Reprod. Dev. 47, 407-13.

Keefer, C.L. \& Schuetz, A.W. (1982). Spontaneous activation of ovulated rat oocytes during in vitro culture. J. Exp. Zool. 224, 371-7.

Kono, T., Shinoda, Y. \& Tsunoda, Y. (1988). Nuclear transplantation of rat embryos. J. Exp. Zool. 248, 303-5.

Kono, T., Kwon, O.Y., Watanabe, T. \& Nakahara, T. (1992). Development of mouse enucleated oocytes receiving a nucleus from different stages of the second cell cycle. $J$. Reprod. Fertil. 94, 481-7.

Kwon, O.Y. \& Kono, T. (1996). Production of identical sextuplet mice by transferring metaphase nuclei from 4-cell embryos. Proc. Natl. Acad. Sci. USA 93, 13010-3.

McGrath, J. \& Solter, D. (1983). Inability of mouse blastomere nuclei transferred to enucleated zygotes to support development in vitro. Science 226, 1317-19.

Miyoshi, K., Kono, T. \& Niwa, K. (1997). Stage-dependent development of rat 1-cell embryos in a chemically defined medium after fertilization in vivo and in vitro. Biol. Reprod. 56, 180-5.

Ono, Y., Shimozawa, N., Ito, M. \& Kono, T. (2001). Cloned mice from fetal fibroblast cells arrested at metaphase by a serial nuclear transfer. Biol. Reprod. 64, 44-50.
Roh, S., Du, Z.T., Fida, S., Handford, C., Malakooti, N., Morrison, J.R. \& Trounson, A.O. (2002). Effect of timing of oocyte activation on rat cloning using neural stem cell nuclei (abstract). Biol. Reprod. Suppl. 66, 239.

Smith, L.C. \& Wilmut, I. (1994). Control of cleavage and further development in vitro in reconstituted two-cell mouse embryos. J. Reprod. Fertil. 100, 323-9.

Tsunoda, Y. \& Kato, Y. (1997). Full-term development after transfer of nuclei from 4-cell and compacted morula stage embryos to enucleated oocytes in the mouse. J. Exp. Zool. 278, 250-4.

Tsunoda, Y. \& Kato, Y. (1998). Not only inner cell mass cell nuclei but also trophectoderm nuclei of mouse blastocysts have a developmental totipotency. J. Reprod. Fertil. 113, 181-4. Tsunoda, Y., Yasui, T., Shinoda, Y., Nakamura, K., Uchida, T. \& Sugie, T. (1987). Full term development of mouse blastomere transplanted into enucleated two-cell embryos. J. Exp. Zool. 242, 147-51.

Von Beroldingen, C.H. (1981). The developmental potential of synchronized amphibian cell nuclei. Dev. Biol. 81, $115-26$.

Wakayama, T. \& Yanagimachi, R. (2001). Effect of cytokinesis inhibitors, DMSO and the timing of oocyte activation on mouse cloning using cumulus cell nuclei. Reproduction 122, $49-60$.

Wakayama, T., Perry, A.C.F., Zuccotti, M., Johnson, K.R. \& Yanagimachi, R. (1998). Full-term development of mice from enucleated oocytes injected with cumulus cell nuclei. Nature 394, 369-74. 